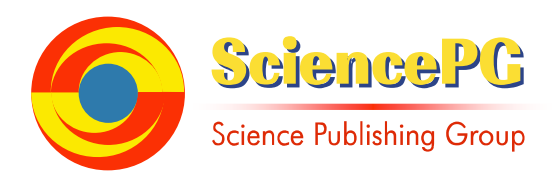

\title{
Uncertainty and Risk Factors Assessment for Cross-Country Pipelines Projects Using AHP
}

\author{
Hesham Abd El Khalek ${ }^{1}$, Remon Fayek Aziz ${ }^{2}$, Hamada Kamel ${ }^{3, ~ * ~}$ \\ ${ }^{1}$ Construction Engineering and Management, Faculty of Engineering, Alexandria University, Alexandria, Egypt \\ ${ }^{2}$ Construction Engineering and Management, Faculty of Engineering, Alexandria University, Egypt \\ ${ }^{3}$ Faculty of Engineering, Alexandria University, Alexandria, Egypt
}

\section{Email address:}

heshamkhaleq@gmail.com (H. A. El Khalek), remon_fayek@hotmail.com (R. F. Aziz), hamadakamel1974@gmail.com (H. Kamel)

\section{To cite this article:}

Hesham Abd El Khalek, Remon Fayek Aziz, Hamada Kamel. Uncertainty and Risk Factors Assessment for Cross-Country Pipelines Projects Using AHP. American Journal of Civil Engineering. Vol. 4, No. 1, 2016, pp. 12-23. doi: 10.11648/j.ajce.20160401.12

\begin{abstract}
Infrastructure cross-country pipelines projects carry out higher risk than traditional because they entail high capital outlays and intricate site conditions. The high-risk exposure associated with infrastructure cross-country pipelines projects needs special attention from contractors to analyze and manage their risks. They cannot be eliminated but can be minimized or transferred from one project stakeholder to another. Therefore, current research aims for identifying the risk factors that affect infrastructure cross-country pipelines projects based on experts experience and company's point of view which participated in similar projects. The risk factors classified under two categories to company level risks and project level risks. The risk factors were assessed using risk assessment models that facilitate this assessment procedure, prioritize these projects based upon its risk indexes and evaluate risk contingency value. Analytical hierarchy process (AHP) used to evaluate risk factors weights (likelihood) and FUZZY LOGIC approach to evaluate risk factors impact (Risk consequences) using software aids such as EXCEL and MATLAB software, accordingly risk indexes for both company level and project level evaluated and overall project risk index determined. Five case studies in different countries were selected to determine the highest risk factors and to implement the designed models and test its results. Results show that project no 3 in Iraq conquer the highest risk index (39.75\%); however, project 5 in Egypt has the lowest risk index (5.24\%). Results of risk factors in other countries are (32.81\%) in Emirates, $(17.27 \%)$ in Saudi Arabia and (11.67\%) in Libya. Therefore, the developed model can be used to sort projects based upon risk, which facilitate company's decision of which project can be pursued.
\end{abstract}

Keywords: Risk Management, International Construction, Risk Factors, Optimization Model,

Analytic Hierarchy Process $(A H P)$, FUZZY LOGIC Approach, MATLAB Software, Validation Process

\section{Introduction}

The business of construction has changed a great deal resulting from the effects of growing globalization and competition [22]. The fast-growing international trade and developments, such as the World Trade Organization agreements [32] and the Asia-Pacific Economic Cooperation forum (APEC, 2003) have provided new opportunities to the construction industry. Facilitated by sophisticated communication technologies, advanced project management, and by profits attraction, large-scale projects are no longer local events but international affairs involving parties of different nations [13, 21, 22].

Infrastructure such pipelines project is by its nature the corner stone of our society. It lays the foundation for a healthy economy and civilization. Such projects carry out higher risk than traditional because they spend high capital outlays and have complicated site conditions. Generally, projects that are implemented in the infrastructure field as cross-country pipeline projects are considered as investments, due to the high initial cost and the project's long time horizon.

Risks cause cost overrun and schedule delay in many projects. The effectiveness of risk management becomes an important issue in project management. To make risk management more efficient and effective, all parties must understand risk responsibilities, risk event conditions, risk preference, and risk management capabilities. There are many types of potential sources of risk and uncertainty that affect infrastructure cross-country pipelines projects. These 
sources of risk and uncertainty include political, economical, cultural, market, and technical risks that might reduce the contractor(s) and/or subcontractor(s) profit. It is essential that contractors and subcontractors conquer these sources of risk and uncertainty. $[1,13,30,3,9,16]$.

\section{Background}

A cross-country pipeline construction projects are exposed to an uncertain environment due to its enormous size (physical, manpower requirement and financial value), complexity in design technology and involvement of external factors. These uncertainties can lead to several changes in project scope during the process of project execution. Unless the changes are properly controlled, the time, cost and quality goals of the project may never be achieved [23].

The cross-country petroleum pipelines are sensitive for risks because they traverse through varied terrain covering crop fields, forests, rivers, populated areas, desert, Hills, sea bed and offshore $[13,4,6,23]$. Pipelines represent critical infrastructure can create significant social and environmental impacts, such pipeline exposed to natural disasters (such as landslides, earthquakes). [3].

Large-scale construction projects are exposed to an uncertain environment because of such factors as planning and design complexity, presence of various interest groups (project owner, owner's project group, consultants, contractors, vendors etc.), resources (materials, equipment, funds, etc.) availability, climatic environment, the economic and political environment and statutory regulations [30, 31, 23].

Sources of risk and uncertainty always exist in construction projects and often cause schedule delay or cost overrun [5, 33, and 36]. Project risk is defined as "the exposure to loss/gain", "the probability of occurrence of loss/gain multiplied by its respective magnitude" [15], Cooper and Chapman [7] define it as "exposure to the possibility of economic or financial loss or gain, physical damage or injury, or delay, as a consequence of the uncertainty associated with pursuing a particular course of action." Al-Bahar [2] defines it as "the exposure to the chance of occurrences of events adversely or favorably affecting project objectives as a consequence of uncertainty.

Project management considers risk management as one of the key knowledge areas for managers [33, 37].

\subsection{Risk Management Process}

Risks do not exist in isolation but evolve in the context of a project. In order to reduce the potentially disastrous consequences of risks, project managers seek to understand them and deal with them appropriately. Project managers have given this process the name Project Risk Analysis and Management (PRAM) [5]. This process can be broken up into a number of components, identification, assessment, allocation, mitigation and management.

\subsection{Risk Identification}

The first stage of the risk management process is to actually identify the relevant risks to the project. Dias A., [10] stated the aims of this phase are to: 1. Identify all the significant types and sources of risk and uncertainty associated with each of the investment objectives. 2 . Determining Key parameters relating to these objectives ascertain the causes of each risk.3. Assess how risks are related to other risks and how risks should be classified and grouped for evaluation.

There are a number of methods available to project planners when seeking to identify the relevant risks to their project. Chapman [5] has assessed the benefits of three of the most commonly used methods, Brain storming and nominal group technique and Delphi technique.

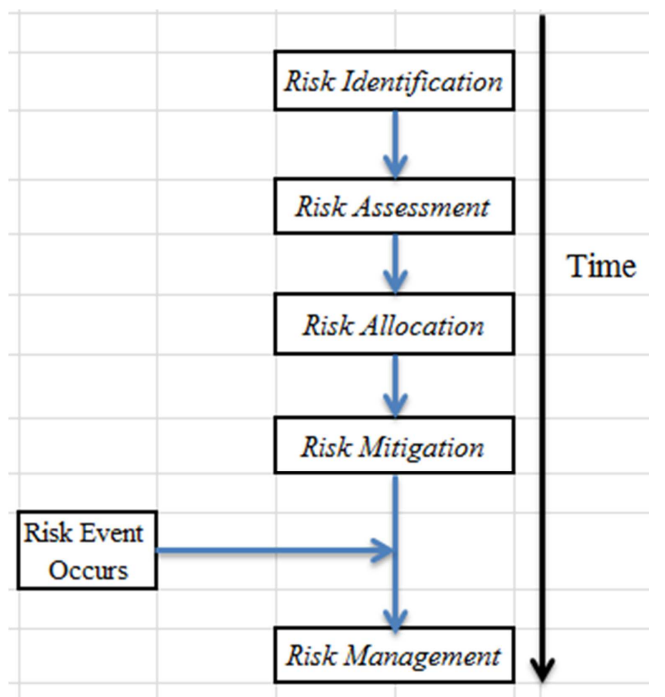

Figure 1. The sequence of risk management process.

\subsection{Risk Assessment}

Risk assessment is the process of reviewing and understanding risks in order to determine their significance for the project and its outcomes. This process include determining the relative importance of all risks which can impact the project and estimating the probability of the risk occurring and the likely size of the risk. Risk assessment is important as it help project developers to concentrate theirre sources (in terms of both time and money) in the areas where they can make the most significant contribution to the eventual project outcome. It also allows project developers to understand which aspects of the project are the most sensitive to risk events. There are two types of method which may be used for risk assessment. [29].

\subsection{Risk Allocation}

Once project risks have been identified and assessed, they are usually allocated to one of the parties involved. The party that becomes responsible for the risk must bear any costs associated with its crystallization. 


\subsection{Risk Mitigation}

Risk mitigation is the process of understanding the risks to which a project is exposed and attempting to reduce the significance of those risks prior to their occurrence. There are many types of risk mitigation measures available. Suitable methods vary depending on the type of risk and the characteristics of the organization that is mitigating that risk.[10].

\subsection{Risk Management}

Risk management is the process of understanding how a risk has affected a particular project and putting in place measures to reduce the effect of that risk event. The aim of risk management is to restore the project to its 'pre-risk' state as quickly as possible and with the smallest possible cost [29].

Risk and uncertainty of cross country pipelines construction projects did not receive sufficient attention from researchers. Therefore, current research is trying to open this area by studying several case studies in cross country pipelines construction projects. It only considers the first two steps of risk management: identification and assessment. The following sections will explain risk identification and assessment model building for cross country pipelines construction projects.

\section{Research Objectives}

The objectives of current research are:

1. Identify main risk and uncertainty factors and their subfactors that affect projects for the company level and the project level in cross country pipelines projects.

2. Evaluate the most risky factors that affect infrastructure cross-country pipelines projects using software aids.

3. Building risk assessment model and apply the proposed model on real cases.

\section{Study Methodology}

The first stage in this research methodology, is to specify the several variables (numerical and linguistic), that would affect the project. This will be done by gathering all the related variables from database of previous projects, the project environment (host country conditions, project's characteristics and location). The project risk decision factors selection based upon evaluation of a wide range of risk decision factors and their sub factors gathered from the literature. The second stage is to identify those variables, remove the redundant variables, and classifies them, Then, grouping these decision factors under main categories according to their relativeness.

The third stage, Questionnaire was designed to rate the significant level of project risk factors with in each category of risks by using five - point scale (1-5) to build the risk factors model in both company and project level in order to assign the most important factors and remove ineffective factors. The fourth stage, two risk index (R) models in both company and project levels will be designed to assess the effect of sources of risk and uncertainty on construction project based on the equation (1) which is adapted from (Dias, 1996) [10]..

RISK=LIKELIHOOD X CONSEQUENCE

$$
\mathrm{R}=\sum_{i=1}^{n} \mathrm{~W}(\mathrm{xi}) * \mathrm{E}(\mathrm{xi})
$$

$\mathrm{R} \quad$ : Risk index for a construction projects.

Wi (xi) : Weight for each risk area i using Eigen value

Ei (xi) : Effect score for each risk factor (xi).

$\mathrm{Xi} \quad$ : Different risk factor (i).

I $\quad: \quad 1,2,3, \ldots \ldots \ldots \ldots, n$.

n : Number of risk factors.

The risk model consists of two parts: risk factors weights (W) and their worth score (E). Risk factors weights will be determined using the AHP; while the worth scores (Risk effectiveness) will be assessed using four approaches, Dias approach [10], Value curve approach according to Zayed [34, 35], New approach according to Salman M. [29] and new approach according Fuzzy logic approach. Finally five case studies have been employed to demonstrate the application of proposed model.

\section{Data Collection}

To identify the risk factors and sub factors in international projects, a questionnaire survey in the form of face-to-face interview was conducted with 93 practitioners, who are experts in the field. The selection of the experts was based on that they work in cross country pipelines projects, participate in international projects or tend to go in new markets. The positions of the participants vary among project managers, project planners, proposals, quality control, estimators, safety, site and cost control engineers from all disciplines from the participated. There are two phases of data collection which are implemented through research displayed in table (1).

Table 1. Study Questionnaires.

\begin{tabular}{lll}
\hline Questionnaire No & Description & Objectives \\
\hline $\begin{array}{l}\text { Over all Data } \\
\text { A. Questionnaire 1 }\end{array}$ & Criteria Development & Building Risk model \\
$\begin{array}{l}\text { Focused Data } \\
\text { B. Questionnaire 2 }\end{array}$ & $\begin{array}{l}\text { AHP, Risk Performance } \\
\text { surveys for five projects }\end{array}$ & Model application \\
\hline
\end{tabular}

\section{Identification of Cross Country Pipelines Projects Risk Factors}

Zayed and Chang [35] proposed one model combining the company and project risks in one model. BU Qammaz [4] identified risk associated with international construction projects (ICPR model) which risk sources were categorized under 5 main categories which are country, inter-country, construction, project team, and contractual issues; and these criteria were believed to best reflect the nature of the 
considered risk sources, The hierarchical representation of risk sources is known as a hierarchal risk breakdown structure (HRBS). Many authors proposed different risk breakdown structures to classify risk in these projects in two categories, in the company management level and in the project management level. Company level risks contain risk factors which connect with the characteristics of the host country. It concerns the political situation, economic conditions, unethical practices, legal system maturity, and the stability and level of security in the country. The factors considered under this category are: bribery, government instability, tension/conflicts/terrorism, bureaucratic difficulties, immaturity/unreliability of legal system, change of regulations/laws (government interventions), and instability of economic conditions (inflation/currency fluctuation) [11, 34, 38].

Different risk breakdown structures to classify risks in project level were proposed reflecting different experts opinions [7], In addition Zayed $\mathrm{T}$ [34] proposed the more importance risk factors in the project level concerning emerging technology usage, contracts and legal issues, resources, design stage, construction stage, quality, and other areas, such as weather, natural causes of delay in addition to physical damages. Based upon literature and cross-country pipelines projects expert's opinions in questionnaire forms,
Risk factors classified under to main classes company and project levels risk factors as displayed in Fig (2).

Twenty two factors have been selected in the company risk level and thirty three factors have been selected in the project risk as the most significant factors affecting the project and forming the risk factors model. Figures 2, 3 and 4 display the risk hierarchy models in both company and project levels. The factors were identified and classified under five main categories in the company risk and nine main categories in the project risk according to their relativeness.

\section{Risk Assessment Model Development}

According to the aforementioned factors, a risk index $(\mathrm{R})$ model is designed to assess the effect of sources of risk and uncertainty on a construction project from contractor (company) prospective the model displayed in figures 2, 3, 4 respectively. It provides a logical, reliable, and consistent method of evaluating potential projects, prioritizing them, and facilitating company's decision in the promotion. The risk index $(\mathrm{R})$ model based upon equation 1 characterizes the various sources of risk and uncertainty in a project and assesses their effect on such project. The R-index consists of two parts: weights of risk factors and sub-factors and their effect score.

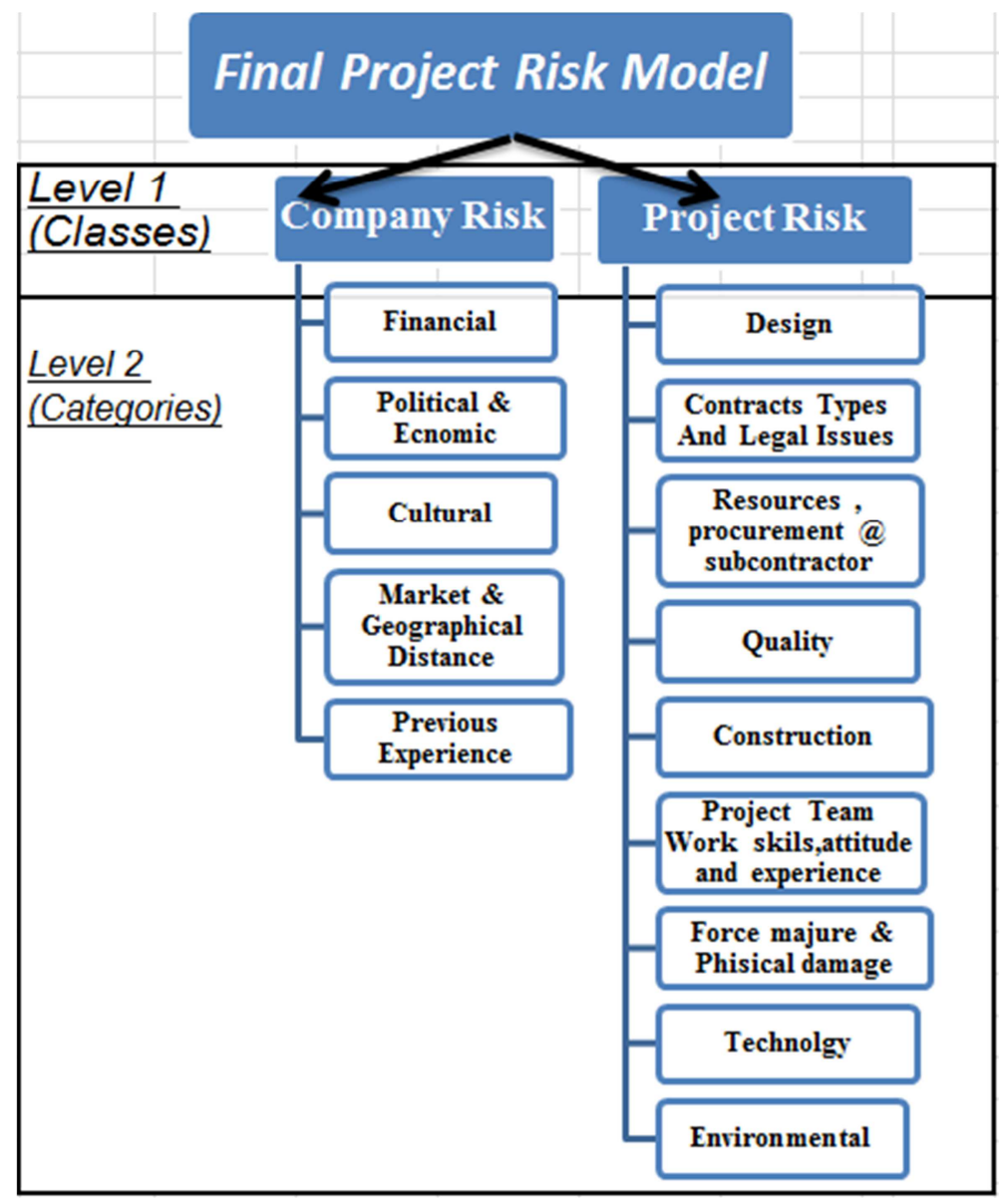

Figure 2. Developed Risk hierarchy model in company and project Levels. 


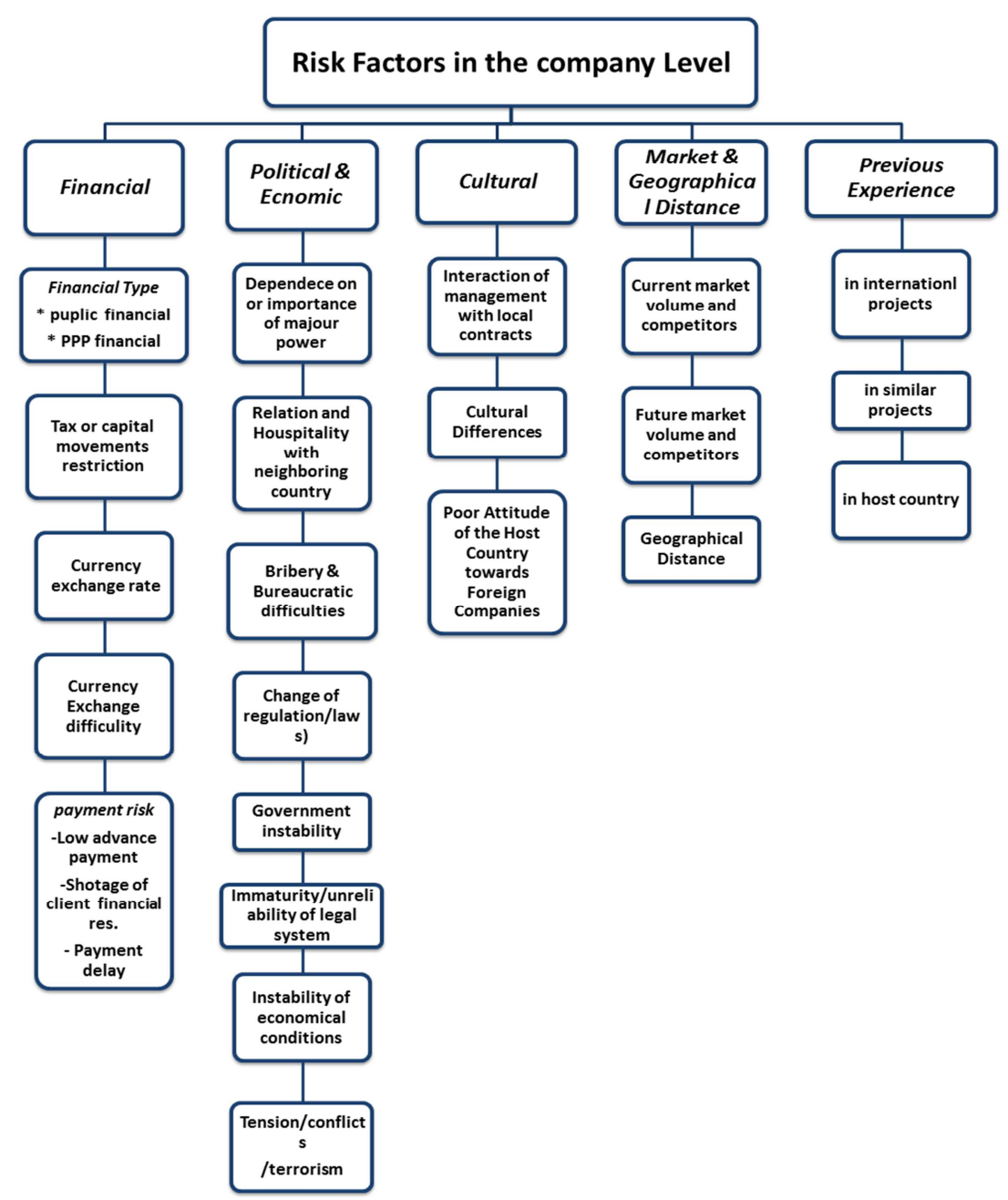

Figure 3. Risk hierarchy model in company Level.

\section{Risk Factors in Project Level}
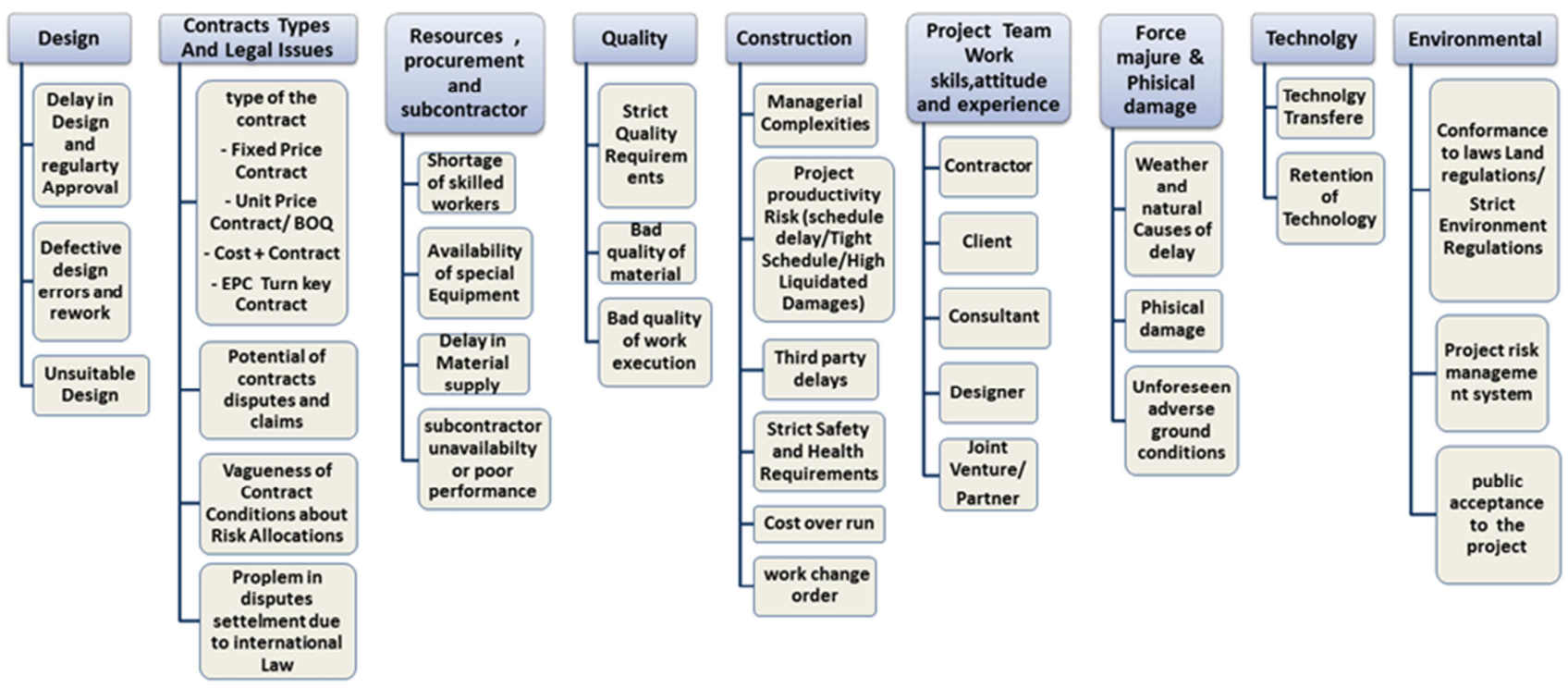

Figure 4. Risk hierarchy model in project Level. 


\section{Model Application}

\subsection{Program Verification for Five Projects}

Five projects in different countries were selected to verify model application, the projects are as follows:

1. Project 1: Nuayyim Field ASL Pipelines project (Saudi Arabia).

2. Project 2: Habshan Saiem Plant and Pipelines development (Arab United of Emirates).

3. Project 3: Nasria Pipeline /16 "/ 200km/Oil Pipeline Company (OPC) (Iraq).

4. Project 4: Sareer Plant / Entisar Field Pipeline 195 KM (Libya).

5. Project 5: Desouq Fields Development pipelines - 132 Km (Egypt).

\subsection{Part 1: AHP Survey}

It was required form the participants to make pairwise comparison among risk factors and risk sub factors represent the relative importance between them based on the numerical scale (1-9) using Analytical Hierarchy Process (AHP) Figure 5 provides an example to explain the pair wise process. The assignment of weights requires logical and analytical thinking, so it is preferred to focusing on the participants who have good experience and knowledge under each case study to participate in the AHP survey questionnaire to ensure that only valid and good quality data are acquired. It is assumed that the group members will carry out necessary brainstorming sessions and reach to a consensus for the required tasks. In other words, rather than asking the same questions to individual members separately, only one response is received from the group and it is believed to represent the democratic majority point of view of the group. $[25,26,27,28,18]$

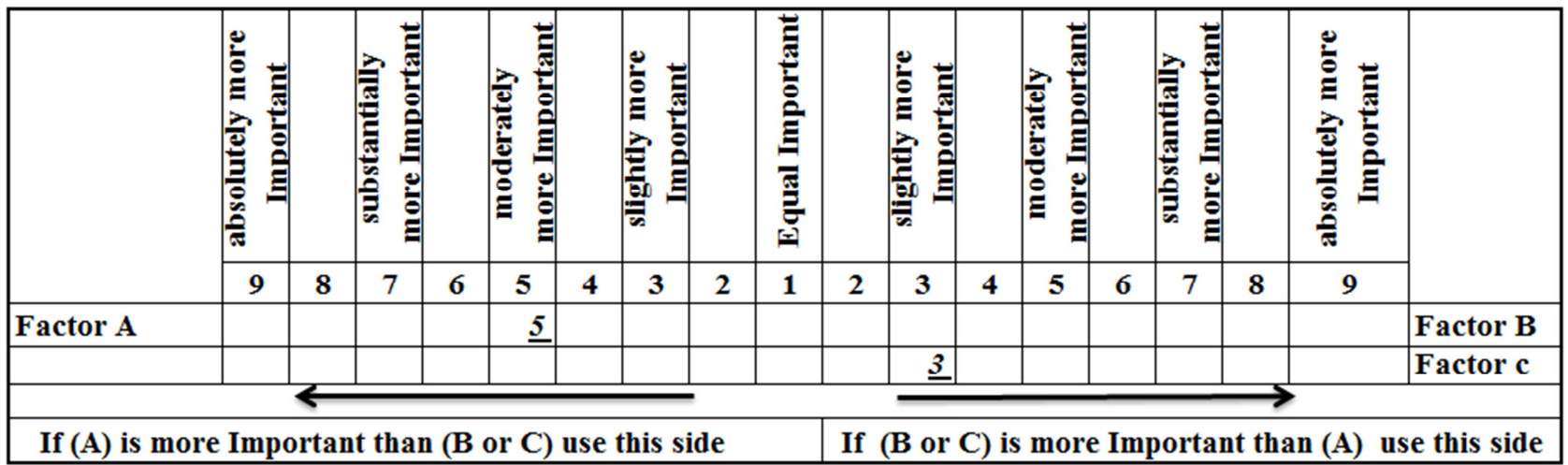

Figure 5. An example was provided to explain the pairwise process.

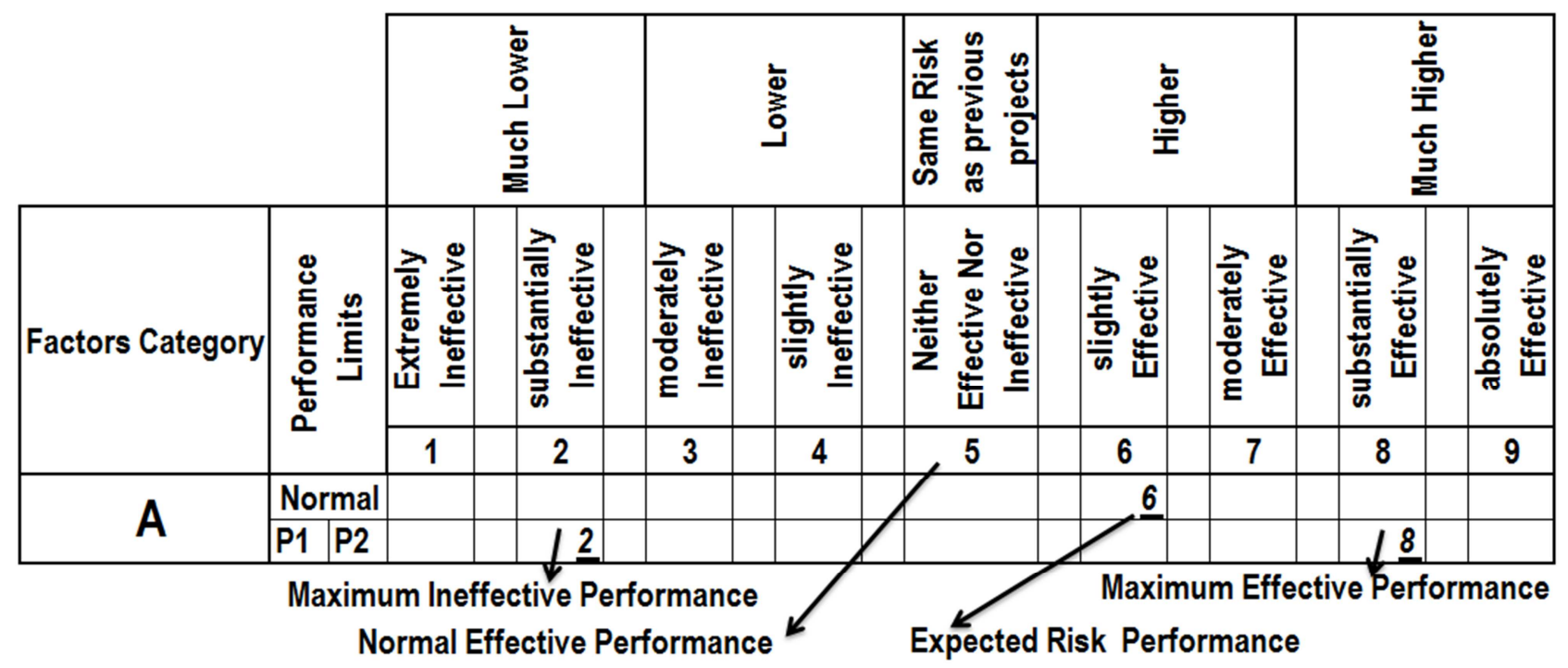

Figure 6. An example was provided to explain Performance scale.

\subsection{Part 2: Assigning Risk Performance}

It was required form the participants to assign 3 point represent the low risk performance $(\mathrm{P} 1)$, the high point of risk performance $(\mathrm{P} 2)$ and the Expected risk performance $(\mathrm{P}$ Expected) for all sub factors in both company and project risk factors based on the numerical scale (1-9). Figure 6 provides 
an example to explain Assigning Risk Performance for each risk factor. The main points in the performance scale are:

Minimum Risk Performance (P1): this point represents maximum Ineffective risk performance. It indicates the risk factor impact if things go well (optimistic Impact).

Maximum Risk Performance (P2): this point represents maximum effective risk performance. It refers to the risk factor impact if things do not go well (pessimistic Impact).

Expected Risk Performance $\left(P_{\text {Expected }}\right)$ : This point represents best estimate of the risk impact (most likely impact).

Neither effective nor ineffective point: This point represents normal risk performance which means the same risk as previous projects.

Extremely Ineffective: The lowest risk point in the performance scale. It is means there is extremely no risk.

Absolutely Effective: The highest risk point in the performance scale. It is means there is extremely high risk.

Excel spread sheet software was designed to solve the weights, impacts and receive the results obtained from fuzzy program (Expected Risk Performance ( $P_{\text {Expected }}$ ), hence the overall risk can be determined based on equation $1[29,34]$ for four risk evaluation methods.

DIAS approach [10], P2=100 approach [34, 35], P2 only [29] and new model based on FUZZY LOGIC approach (not scope of this paper due to limited space reason).

\subsection{Model Results}

Results of risk factors in company level based on the new model of fuzzy approach displayed in table 2 and figures 7, 8 reveal that Current market volume and competitors, previous experience in host country, have the highest risk value in project no (1) in Saudi Arabia, On the other hand Shortage of skilled workers, Subcontractor unavailability or poor performance and Strict Quality Requirements have the highest risk value in project level.

Table 2. Low and high risk factors in each project in different countries under current study in both Company and project level based on new model of fuzzy approach.

\begin{tabular}{|c|c|c|c|c|c|c|c|}
\hline Project & Country & Project & Level & High Risk Factors & High Risk value & Low Risk Factors & Low Risk value \\
\hline \multirow{8}{*}{ Project (1) } & \multirow{8}{*}{$\begin{array}{l}\text { Nuayyim } \\
\text { Field ASL } \\
\text { Pipelines }\end{array}$} & \multirow{8}{*}{$\begin{array}{l}\text { Nuayyim } \\
\text { Field ASL } \\
\text { Pipelines }\end{array}$} & \multirow{4}{*}{$\begin{array}{l}\text { Company } \\
\text { risk }\end{array}$} & $\begin{array}{l}\text { Current market volume and } \\
\text { competitors }\end{array}$ & 0.0941 & Tension/conflicts/terrorism & 0.0009 \\
\hline & & & & PR EXP in host country & 0.0889 & Change of regulation/laws) & 0.0008 \\
\hline & & & & $\begin{array}{l}\text { Future market volume and } \\
\text { competitors }\end{array}$ & 0.0397 & Government instability & 0.0007 \\
\hline & & & & & & $\begin{array}{l}\text { Instability of economical } \\
\text { conditions }\end{array}$ & 0.0007 \\
\hline & & & \multirow{4}{*}{$\begin{array}{l}\text { Project } \\
\text { Risk }\end{array}$} & Shortage of skilled workers & 0.0742 & Project risk management system & 0.0011 \\
\hline & & & & $\begin{array}{l}\text { subcontractor unavailabilty } \\
\text { or poor performance }\end{array}$ & 0.0740 & $\begin{array}{l}\text { Unforeseen adverse ground } \\
\text { conditions }\end{array}$ & 0.0009 \\
\hline & & & & Strict Quality Requirements & 0.0535 & Physical damage & 0.0007 \\
\hline & & & & & & $\begin{array}{l}\text { Joint Venture Team Work skils, } \\
\text { attitude and experience }\end{array}$ & 0.0003 \\
\hline \multirow{8}{*}{ Project (2) } & \multirow{7}{*}{$\begin{array}{l}\text { United } \\
\text { arab of } \\
\text { Emarates }\end{array}$} & \multirow{7}{*}{$\begin{array}{l}\text { plant and } \\
\text { Pipelines of } \\
\text { Habshan } \\
\text { Saiem }\end{array}$} & \multirow{4}{*}{$\begin{array}{l}\text { Company } \\
\text { risk }\end{array}$} & Change of regulation/laws) & 0.1089 & Currency exchange rate & 0.0018 \\
\hline & & & & $\begin{array}{l}\text { Dependence on or } \\
\text { importance of major power }\end{array}$ & 0.0929 & Cultural Differences & 0.0015 \\
\hline & & & & $\begin{array}{l}\text { Future market volume and } \\
\text { competitors }\end{array}$ & 0.0717 & $\begin{array}{l}\text { Poor Attitude of the Host Country } \\
\text { towards Foreign Companies }\end{array}$ & 0.0015 \\
\hline & & & & & & $\begin{array}{l}\text { Tax or capital movements } \\
\text { restriction }\end{array}$ & 0.0012 \\
\hline & & & \multirow{3}{*}{$\begin{array}{l}\text { Project } \\
\text { Risk }\end{array}$} & Shortage of skilled workers & 0.0972 & $\begin{array}{l}\text { Potential of contracts disputes and } \\
\text { claims }\end{array}$ & 0.0023 \\
\hline & & & & Delay in Material supply & 0.0617 & Bad quality of work execution & 0.0023 \\
\hline & & & & Cost over run & 0.0551 & Bad quality of material & 0.0023 \\
\hline & \multirow{9}{*}{ IRAQ } & \multirow{9}{*}{$\begin{array}{l}\text { Nasria } \\
\text { Pipeline } 16 \\
\text { 200kmOil }\end{array}$} & \multirow{5}{*}{$\begin{array}{l}\text { Company } \\
\text { risk }\end{array}$} & & & public acceptance to the project & 0.0018 \\
\hline \multirow{8}{*}{ Project (3) } & & & & Tension/conflicts/terrorism & 0.1045 & $\begin{array}{l}\text { Immaturity/unreliability of legal } \\
\text { system }\end{array}$ & 0.0044 \\
\hline & & & & $\begin{array}{l}\text { Dependece on or importance } \\
\text { of majour power }\end{array}$ & 0.0720 & $\begin{array}{l}\text { Relation and Hospitality with } \\
\text { neighboring country }\end{array}$ & 0.0032 \\
\hline & & & & $\begin{array}{l}\text { Previous Experience in host } \\
\text { country }\end{array}$ & 0.0702 & Cultural Differences & 0.0024 \\
\hline & & & & Geographical Distance & 0.0508 & $\begin{array}{l}\text { Poor Attitude of the Host Country } \\
\text { towards Foreign Companies }\end{array}$ & 0.0008 \\
\hline & & & \multirow{4}{*}{$\begin{array}{l}\text { Project } \\
\text { Risk }\end{array}$} & $\begin{array}{l}\text { subcontractor unavailabilty } \\
\text { or poor performance }\end{array}$ & 0.0753 & $\begin{array}{l}\text { Contractor Team Work skills, } \\
\text { attitude and experience }\end{array}$ & 0.0026 \\
\hline & & & & $\begin{array}{l}\text { Defective design errors and } \\
\text { rework }\end{array}$ & 0.0511 & public acceptance to the project & 0.0024 \\
\hline & & & & Managerial Complexities & 0.0464 & $\begin{array}{l}\text { Potential of contracts disputes and } \\
\text { claims }\end{array}$ & 0.0017 \\
\hline & & & & & & Type of the contract & 0.0013 \\
\hline Project (4) & Lebia & Sareer Plant / & Company & Previous Experience in host & 0.1058 & Instability of economical & 0.0014 \\
\hline
\end{tabular}




\begin{tabular}{|c|c|c|c|c|c|c|c|}
\hline Project & Country & Project & Level & High Risk Factors & High Risk value & Low Risk Factors & Low Risk value \\
\hline \multirow{14}{*}{ Project (5) } & \multirow{14}{*}{ Egypt } & \multirow{9}{*}{$\begin{array}{l}\text { Entisar field } \\
\text { Pipeline } 195 \\
\mathrm{~km}\end{array}$} & \multirow[t]{5}{*}{ risk } & country & & conditions & \\
\hline & & & & $\begin{array}{l}\text { Current market volume and } \\
\text { competitors }\end{array}$ & 0.0677 & Tension/conflicts/terrorism & 0.0013 \\
\hline & & & & $\begin{array}{l}\text { Future market volume and } \\
\text { competitors }\end{array}$ & 0.0478 & $\begin{array}{l}\text { Relation and hospitality with } \\
\text { neighboring country }\end{array}$ & 0.0007 \\
\hline & & & & & & Government instability & 0.0004 \\
\hline & & & & Cost over run & 0.0353 & Type of the contract & 0.0026 \\
\hline & & & \multirow[t]{3}{*}{$\begin{array}{l}\text { Project } \\
\text { Risk }\end{array}$} & Unsuitable Design & 0.0291 & $\begin{array}{l}\text { Conformance to laws Land } \\
\text { regulations/Strict Environment } \\
\text { Regulations }\end{array}$ & 0.0017 \\
\hline & & & & $\begin{array}{l}\text { Weather and natural Causes } \\
\text { of delay }\end{array}$ & 0.0263 & public acceptance to the project & 0.0008 \\
\hline & & & & payment risk & 0.0571 & $\begin{array}{l}\text { Relation and hospitality with } \\
\text { neighboring country }\end{array}$ & 0.0009 \\
\hline & & & \multirow[t]{3}{*}{$\begin{array}{l}\text { Company } \\
\text { risk }\end{array}$} & $\begin{array}{l}\text { Instability of economical } \\
\text { conditions }\end{array}$ & 0.0460 & $\begin{array}{l}\text { Dependence on or importance of } \\
\text { majour power }\end{array}$ & 0.0009 \\
\hline & & \multirow{5}{*}{$\begin{array}{l}\text { Desouq } \\
\text { Fields } \\
\text { development } \\
\text { pipelines - } \\
132 \mathrm{Km}\end{array}$} & & $\begin{array}{l}\text { Previous Experience in zoon } \\
\text { area }\end{array}$ & 0.0158 & $\begin{array}{l}\text { Interaction of management with } \\
\text { local contracts }\end{array}$ & 0.0007 \\
\hline & & & & Delay in Material supply & 0.0680 & $\begin{array}{l}\text { Conformance to laws Land } \\
\text { regulations/Strict Environment } \\
\text { Regulations }\end{array}$ & 0.0016 \\
\hline & & & \multirow[t]{3}{*}{$\begin{array}{l}\text { Project } \\
\text { Risk }\end{array}$} & $\begin{array}{l}\text { Delay in Design and } \\
\text { regularty Approval }\end{array}$ & 0.0322 & Physical damage & 0.0014 \\
\hline & & & & & & work change order & 0.0010 \\
\hline & & & & & & public acceptance to the project & 0.0007 \\
\hline
\end{tabular}

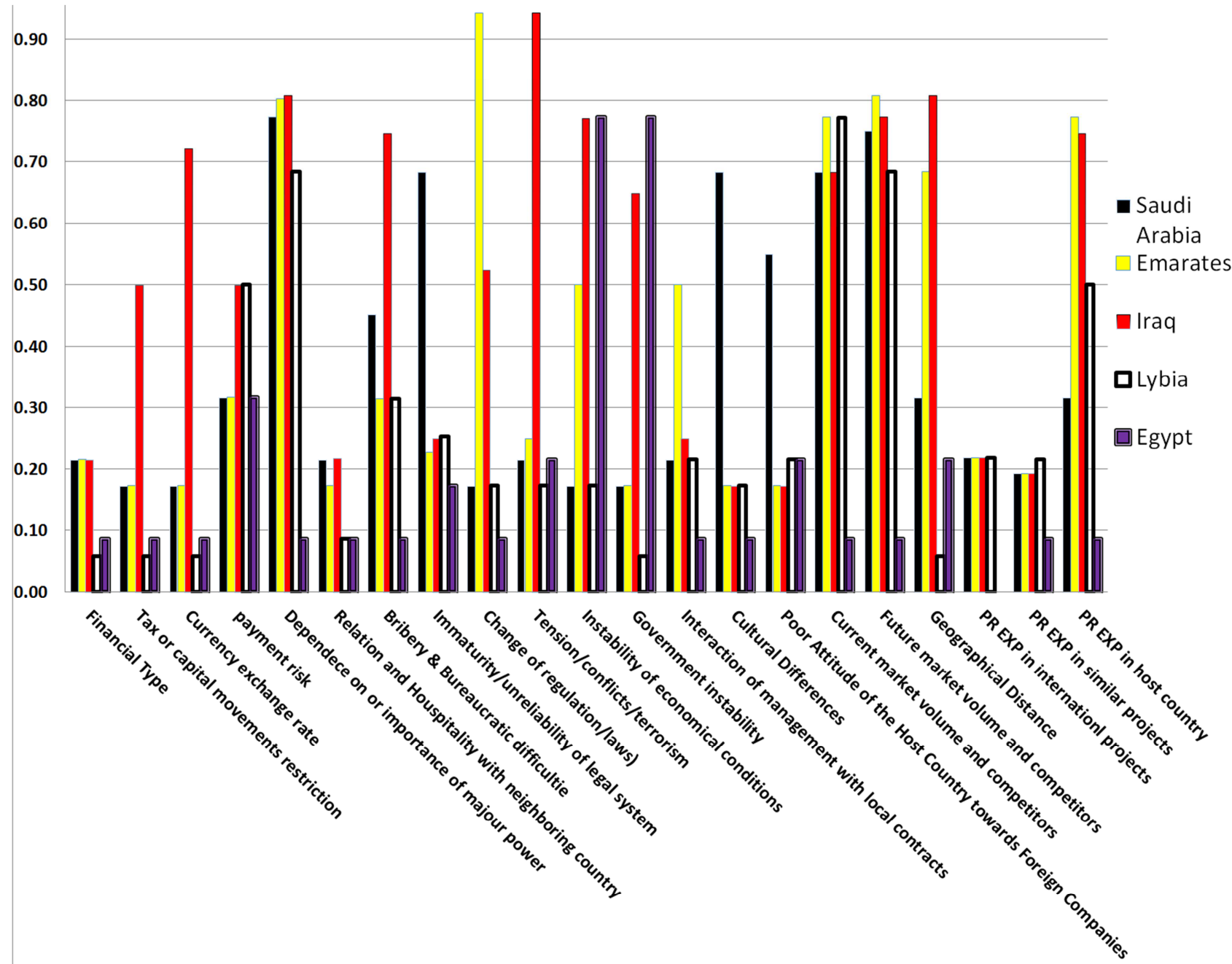

Figure 7. Risk attributes values in company level for each project (Model based on fuzzy approach). 
The Change of regulation/laws, dependence or importance of major power, Future market volume and competitors, current market volume and competitors and geographical distance have the highest risk value in company level in project no (2) in Emirates, in addition Shortage of skilled workers and Delay in Material supply have the highest risk value in project level.

Tension/conflicts/terrorism, dependence on or importance of major power and previous experience in host country have the highest risk value in company level in project no (3) in Iraq, On the other hand subcontractor unavailability or poor performance and defective design errors and rework have the highest risk value in project level. previous experience in host country and Current market volume and competitors have the highest risk value in company level in project no (4) in Libya, On the other hand Cost overrun, unsuitable design and weather and natural Causes of delay have the highest risk value in project level.

Payment risk and Instability of economic conditions have the highest risk value in company level in project no (5) in Egypt, on the other hand delay in material supply and Delay in Design and regularity Approval have the highest risk value in project level.

The above analysis indicates that previous experience in host country attribute, Current market volume and competitors, The Change of regulation/laws, dependence or importance of major power and payment risk and Instability are considered high risk in the five existed profile projects that mean, the decision makers should concentrate well on such attributes to decrease their risk before proceeding with similar to their project. Also The above analysis indicates that availability of resources factors is considered high risk in the most existed profile projects that mean, the decision makers should concentrate well on such attributes to decrease their risk before proceeding with their project by making sure that the project local resources are available when needed and the required imported resources with their paper works (type, cost, import licenses, taxes, delivery time, etc.,) will be settled in the project feasibility study stage. Moreover, from figures $(7,8)$ it is interesting to note that some factors have low risk value and in another project have high risk value based on each project conditions.

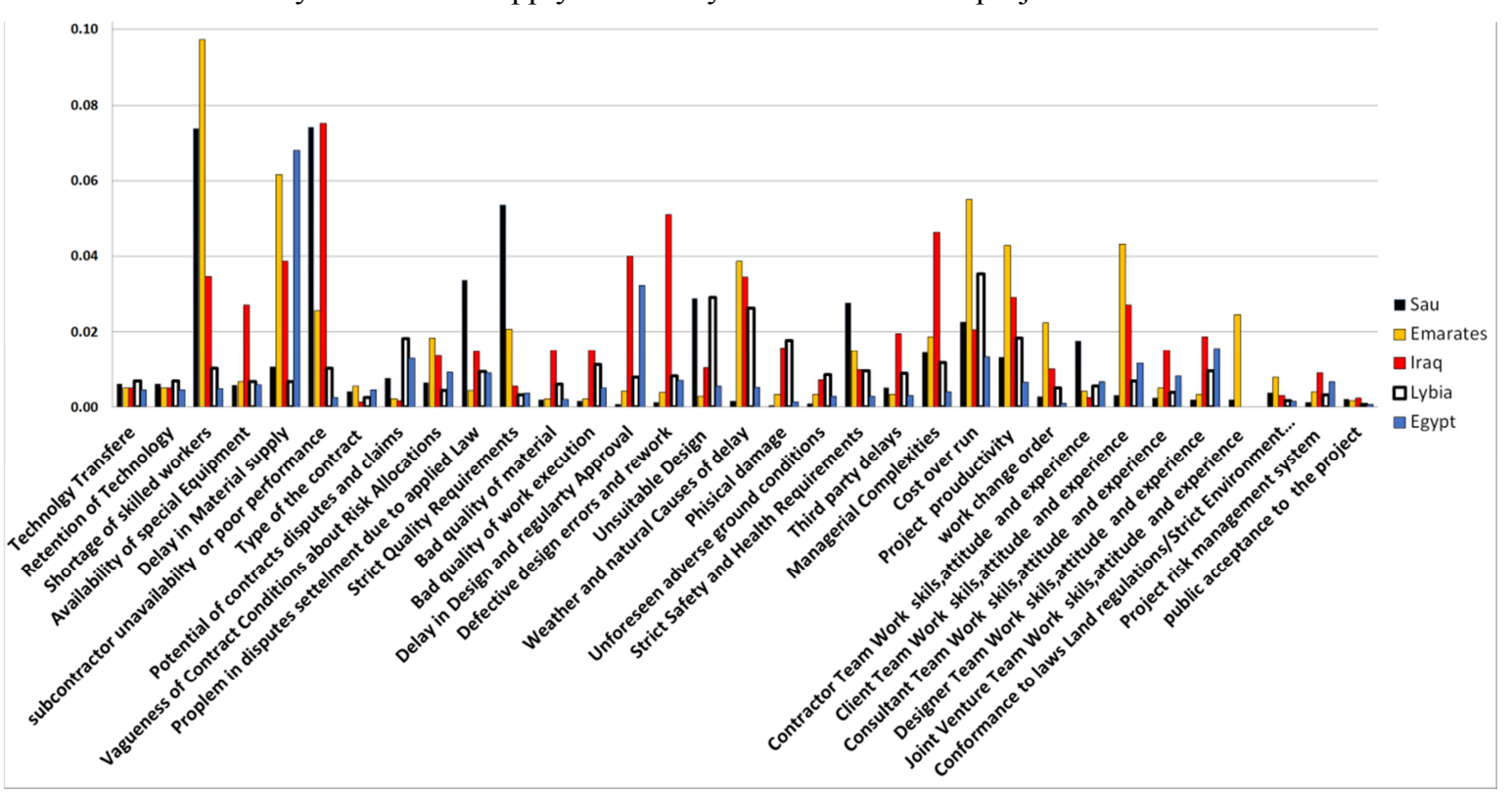

Figure 8. Risk factors values in project level for each project (Model based on fuzzy approach).

\section{Project Risk Index}

The results of Company and project risk indexes for each project conjunction with each approach, gathered from excel program are tabulated in table 3 . The purpose of calculating the risk index for a project is to answer the question "is the project viable enough to be successfully promoted by the contractor and for what extent?" The project risk factors should be revised by decision makers and risky factors possible provisions may be suggested and reevaluated to decrease its risk to catch the accepted limits.

Table 3. Company and project risk indexes and contingency value for each project conjunction with each approach.

\begin{tabular}{llllllll}
\hline Project/Location & \multicolumn{3}{l}{ Project 1: Nuayyim Field ASL Pipelines/Suadi } & \multicolumn{3}{l}{ Project 2: Habshan Saiem plant and Pipelines /Emarates } \\
\hline & Saudi & & & & Emirates & \\
\hline Evaluation & Dias & P2=100 & P2_Only & Fzy/Sgm & Dias & P2=100 & P2_Only \\
\hline Comp Risk index & 0.42 & 0.47 & 0.70 & 0.40 & 0.43 & 0.58 & 0.75 \\
Proj Risk index & 0.49 & 0.48 & 0.72 & 0.44 & 0.49 & 0.58 & 0.78 \\
Final Risk index & $20.9 \%$ & $22.6 \%$ & $50.1 \%$ & $17.3 \%$ & $21.1 \%$ & $33.8 \%$ & 0.58 \\
Fuzzy Risk Value & & & & $\mathbf{2 2 . 6 \%}$ & & & \\
\hline
\end{tabular}


Table 3. Continued.

\begin{tabular}{|c|c|c|c|c|c|c|c|c|c|c|c|c|}
\hline \multirow{3}{*}{$\begin{array}{l}\text { Project / } \\
\text { Location } \\
\text { Evaluation }\end{array}$} & \multicolumn{4}{|c|}{$\begin{array}{l}\text { Project 3: Nasria Pipeline /16 "/ 200km/Oil } \\
\text { Pipeline Company(OPC)/IRAQ }\end{array}$} & \multicolumn{4}{|c|}{$\begin{array}{l}\text { Project 4: Sareer Plant / Entisar field } \\
\text { Pipeline } 195 \text { km (Libya) }\end{array}$} & \multicolumn{4}{|c|}{$\begin{array}{l}\text { Project 5: Desouq Fields development } \\
\text { pipelines - 132 Km/Egypt }\end{array}$} \\
\hline & IRAQ & & & & Libya & & & & Egypt & & & \\
\hline & Dias & $P 2=100$ & P2_Only & Fzy/Sgm & Dias & $P 2=100$ & P2_Only & Fzy/Sgm & Dias & $P 2=100$ & P2_Only & Fzy/Sgm \\
\hline $\begin{array}{l}\text { Comp Risk } \\
\text { index }\end{array}$ & 0.44 & 0.59 & 0.78 & 0.61 & 0.36 & 0.39 & 0.64 & 0.36 & 0.31 & 0.28 & 0.55 & 0.19 \\
\hline $\begin{array}{l}\text { Proj Risk } \\
\text { index }\end{array}$ & 0.52 & 0.62 & 0.80 & 0.65 & 0.35 & 0.34 & 0.53 & 0.32 & 0.46 & 0.37 & 0.64 & 0.27 \\
\hline $\begin{array}{l}\text { Final Risk } \\
\text { index }\end{array}$ & $22.8 \%$ & $36.5 \%$ & $62.0 \%$ & $39.8 \%$ & $12.7 \%$ & $13.4 \%$ & $34.5 \%$ & $11.7 \%$ & $14.3 \%$ & $10.5 \%$ & $34.6 \%$ & $5.2 \%$ \\
\hline $\begin{array}{l}\text { Fuzzy Risk } \\
\text { Value }\end{array}$ & & & & $33.6 \%$ & & & & $19.8 \%$ & & & & $16.2 \%$ \\
\hline
\end{tabular}

High risk projects may be accepted by decision maker as it is if the project quantitative factors are feasible enough to overcome the deficiencies in high qualitative attributes. Table 3 and figures 9, 10, 11 provide the results of risk index for projects under the study for company and project level and overall project risk index.

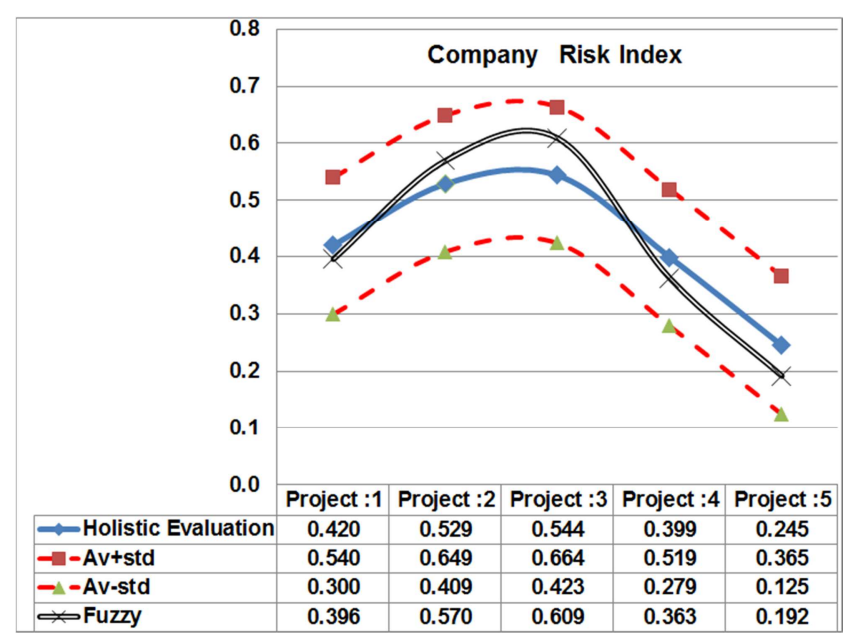

Figure 9. Company risk index in addition to the holistic evaluation according to developed fuzzy model results.

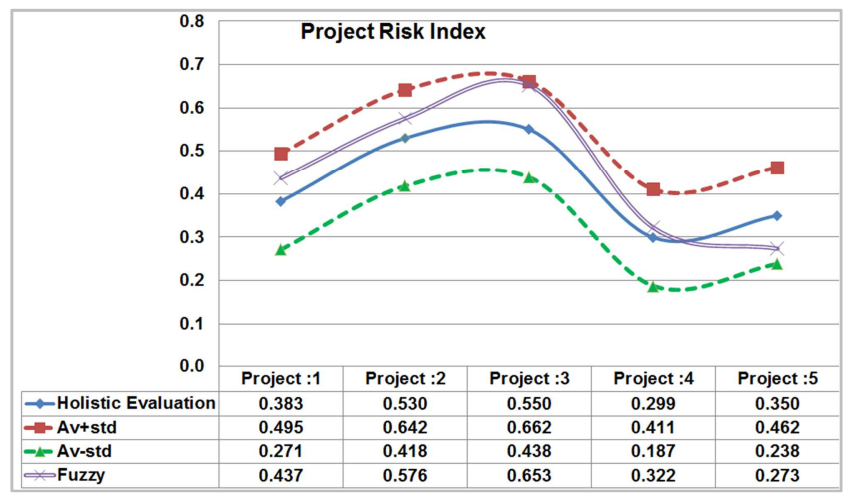

Figure 10. Project risk index in addition to the holistic evaluation according to developed fuzzy model results.

From figure 11, Results of final risk index in the overall project based on fuzzy approach show that project 3 in Iraq conquer the highest risk $(39.75 \%)$; however, project 5 in Egypt has the lowest risk index $(5.24 \%)$. Results of risk factors in other countries are (32.81\%) in Emirates, (17.27\%) in Saudi Arabia and (11.67\%) in Libya. (Final Risk Index =
Company Risk Index * Project Risk Index). Therefore, the developed model can be used to sort projects based upon risk, which facilitate company's decision of which project can be pursued.

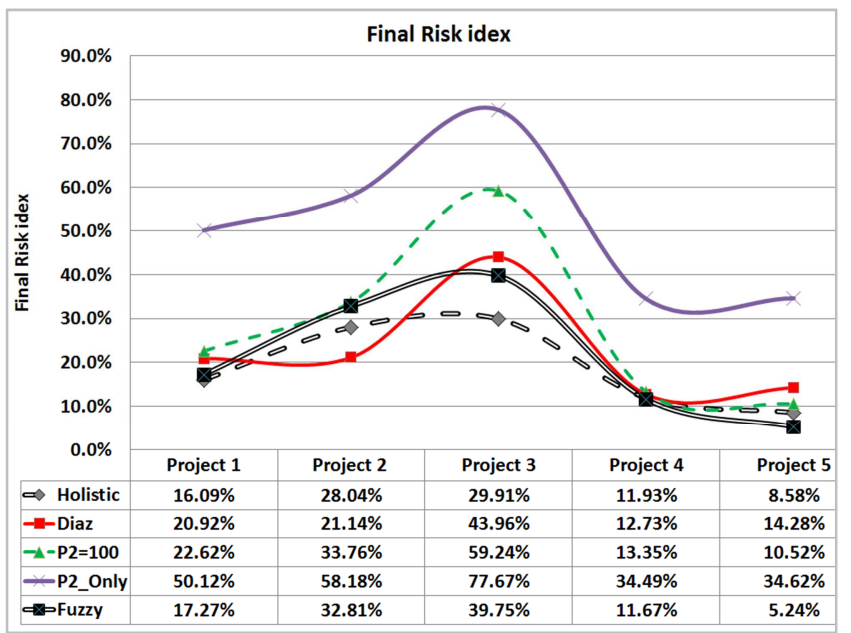

Figure 11. Overall Project risk index for decomposed approach for each project.

\section{Using Risk Index in the Project Feasibility Study}

The purpose of developing the risk model was to help the decision maker in evaluating the feasibility and risk of their project in its preliminary stages and before going forward with the project. The first step on using the risk model consists of assigning the factors importance weights and their performance (quality) levels, developing attributes value curves, and computing the project risk index. Once the factors indexes that forming the total project risk index have been determined, the high risk attributes that affect the total project risk will be known and the decision maker can put the possible strategies to improve their performance level and reevaluate them to increase the project viability or to reject the project if it was not satisfied with the resulting viability.

\section{Conclusion}

Most construction companies are willing to enter into international markets in order to maximize their revenues and 
growth potential benefits. A construction company's decision to expand into international markets must be based on a good understanding of the opportunities and threats associated with international business, as well as the development of company strengths relative to international activities.

This study provided the main factors of risk and uncertainty and their sub-factors in infrastructure cross country pipelines projects; it identified and analyzed these risk factors in direction, company and project levels.

In addition this study proposes Risk hierarchy model in both company and project Levels that performs three functions: identify risk factors in both company and project levels, used to evaluate sources of risk and uncertainty using software aids, accordingly prioritize infrastructure crosscountry pipelines projects according their risk.

Results of risk factors in company level using software aids (fuzzy Logic approach model) show that Current market volume and competitors, previous experience in host country, have the highest risk value in project no (1) in Saudi Arabia, on the other hand Shortage of skilled workers, subcontractor unavailability or poor performance and Strict Quality Requirements have the highest risk value in project level.

The Change of regulation/laws, dependence or importance of major power, Future market volume and competitors, current market volume and competitors and geographical distance have the highest risk value in company level in project no (2) in Emirates, in addition Shortage of skilled workers and Delay in Material supply have the highest risk value in project level.

Tension/conflicts/terrorism, dependence on or importance of major power and previous experience in host country have the highest risk value in company level in project no (3) in Iraq, however subcontractor unavailability or poor performance and defective design errors and rework have the highest risk value in project level.

previous experience in host country and Current market volume and competitors have the highest risk value in company level in project no (4) in Libya, while Cost overrun, unsuitable design and weather and natural Causes of delay have the highest risk value in project level.

Payment risk and Instability of economic conditions have the highest risk value in company level in project no (5) in Egypt, as delay in material supply and Delay in Design and regularity Approval have the highest risk value in project level.

Results show that project no 3 in Iraq conquer the highest risk index (39.75\%); however, project 5 in Egypt has the lowest risk index $(5.24 \%)$. Results of risk factors in other countries are (32.81\%) in Emirates, $(17.27 \%)$ in Saudi Arabia and $(11.67 \%)$ in Libya. For companies that pursues infrastructure cross-country pipelines projects have to consider seriously the previous risks when bidding in international markets. Therefore, the developed model can be used to sort projects based upon risk, which facilitate company's decision of which project can be pursued.

This study developed database of risk information of the most significance risk factors in the international projects in both company and project levels for future references. It is an essential tool to assess the level of risk associated with construction projects under study in the bidding phase in order to take preventive actions.

Risk model and developed decision support tool are company specific. Each company has its own risk knowledge leading to different rules and may have different risk attitudes. Thus, the cases given in this paper should be treated as an example of how the proposed risk model can be utilized in practice rather than a universally accepted evaluation for the risk factors assessment in international construction projects.

\section{Acknowledgements}

The authors express their gratitude to Pr. Hesham Abdel Khalek and Dr Remon Aziz for their generous contribution of time, energy, and knowledge in this study. They also extend their gratitude to all companies that facilitate the authors' research and participate in this research.

\section{References}

[1] Antonio J., Monroy A, Gema S., R., and Lopez A., (2011). "Financial Risks in Construction Projects". African Journal Of Business Management Vol. 5(31), Pp. 12325-12328, 7 December, 2011.

[2] Al-Bahar, J. F. and Crandall, K. C., 1990. "Systematic risk management approach for construction projects", Journal of Construction Engineering and Management, 116(3), 533-546.

[3] Babatunde A, Damian M., Dan Van Horst., Lee Chapman. (20120. "Attacks On Oil Transport Pipelines In Nigeria: a quantitative exploration and possible explanation of observed patterns". applied geography 32 (2012) 636e651.

[4] Bu-Qammaz, A. S. (2007), "risk assessment of international construction projects using the analytic network process", master of science thesis, middle east technical university.

[5] Chapman, C. and Ward, S., (1997). "Project Risk Management Processes, Techniques and Insights", John Wiley, UK.

[6] Cooper D, Grey S, Raymond G and Walker P, 2007, "Project Risk Management Guidelines: Managing Risk in Large Projects and Complex Procurements", John Wiley \& Sons, Ltd, ISBN 0-470-02281-7.

[7] Cooper, D. and Chapman C., (1987), "Risk Analysis for Large Projects- Models, Methods and Cases”, John Wiley, UK.

[8] Carreño, M. L., Cardona, O. D. and Barbat, A. H. "Evaluation of the Risk Management Performance", 250th Anniversary of the 1755 Lisbon Earthquake, technical University Of Catalonia, Barcelona, Spain.

[9] Xiaoping D., And Pheng L., (2012). "Understanding the Critical Variables Affecting the Level of Political Risks In International Construction Projects". KSCE Journal of Civil Engineering (2013) 17(5): 895-907.

[10] Dias A, Ioannou P., (1996). "Company and Project Evaluation Model for Privately Promoted Infrastructure Projects. Journal of Construction Engineering and Management, ASCE 1996; 122(1): 71-82. March. 
[11] Dikmen I, Birgonul T and Han S. (2007). "Using Fuzzy Risk Assessment to Rate Cost Overrun Risk in International Construction Projects". International Journal of Project Management 25 (2007) 494-505.

[12] Enrique Jr., Ricardo C., Vicent E. and Aznar J., (2011). "Analytical Hierarchical Process (AHP) as a Decision Support Tool In Water Resources Management". Journal of Water Supply: Research and Technology-Aqua | 60.6 | 2011.

[13] Gunhan S, Arditi D.(2005). "International expansion decision for construction companies". ASCE, j constreng manage 2005; 131(8): 928-37.

[14] Hyun C., Hyo C. and Seo J. W., (2004). "Risk Assessment Methodology for Underground Construction Projects", ASCE Journal of Construction Engineering and Management, 130, 258-272.

[15] Jaafari A. (2001). "Management of risks: uncertainties and opportunities on projects: time for a fundamental shift". international journal of project management 19 (2001) $89 \pm 101$

[16] John, W., G. and Edward Jr. (2003). "International Project Risk Assessment: Methods, Procedures, and Critical Factors"., A Report of The Center Construction Industry Studies The University Of Texas At Austin.

[17] Liu, A., Wang B, Ma Qingguo B. (2011). The Effects of Project Uncertainty and Risk Management on IS Development Project Performance. A Vendor Perspective International Journal of Project Management 29 (2011) 923-933.

[18] Ludovic V, Marle F, Bocquet J, C. (2011). "Measuring Project Complexity Using the Analytic Hierarchy Process". International Journal of Project Management 29 (2011) 718727.

[19] Ming W. and Hui C. (2003). "Risk Allocation and Risk Handling of Highway Projects In Taiwan". Journal of Management in Engineering, Asce / April 2003.

[20] Mohamed A. and Aminah F., (2010). "Risk management in the construction industry using combined fuzzy FMEA and fuzzy AHP". journal of construction engineering and management, ASCE / September 2010.

[21] Ofori, G. (2000). "Globalization and construction industry development: research opportunities". Construction Management and Economics, 18, 257-262.

[22] Ofori, G and Chan, S L." (2000) Factors influencing growth of construction enterprises in Singapore". Construction Management and Economics (in press).

[23] Prasanta D., (2002). "An Integrated Assessment Model For Cross Country Pipelines". Environmental Impact Assessment Review, 22, (2002) 703-721.

[24] Prasanta D., (2010). "Managing Project Risk Using Combined Analytic Hierarchy Process and Risk Map". Applied Soft Computing 10 (2010) 990-1000.

[25] Saaty TL. The Analytic Hierarchy Process. 1980. New York: Mc graw- Hill, 1980.

[26] Saaty TL. Decision Making For Leaders. Belmont, California: Life Time Leaning Publications, 1985.

[27] Saaty TL. (1990). "How to Make a Decision: The Analytic
Hierarchy Process". European Journal of Operational Research, North-Holland 1990; 48: 9 \pm 26.

[28] Saaty TL, Kearns KP. (1991). "Analytical Planning: The Organization of Systems". The Analytic Hierarchy Process Series 1991; Vol. 4RWS

[29] Salman, A. (2003). "Study Of Applying Build Operate And Transfer Bot Contractual System On Infrastructure Projects In Egypt”. PHD Thesis, Zagazig University, Faculty of Eng.

[30] Seung H., James E. and Jong H., (2005). “Contractor's risk attitudes in the selection of international construction projects". journal of construction engineering and management, ASCE / march 2005 / 283.

[31] Suat, G and David A. (2005). "Factors affecting international construction". journal of construction engineering and management, ASCE / march 2005 / 273.

[32] WTO Annual Report 2004 - World Trade Organization.

[33] Wang M, Chou H. Risk allocation and risk handling of highway projects in Taiwan. J Manage Eng, ASCE 2003; 19(2): 60-8. April.

[34] Zayed T, Mohamed A, Jiayin P. (2008). Assessing Risk And Uncertainty Inherent In Chinese Highway Projects Using AHP "Internal Journal Of Project Management" 26 (2008) 408419.

[35] Zayed, T, and Chang, L. (2002). Prototype Model for BuildOperate-Transfer Risk Assessment. Journal of Management In Engineering / January 2002 / 7.

[36] Zayed TM, Halpin DW. Quantitative assessment for piles productivity factors. J Constr Eng Manage, ASCE 2004; 130(3): 405-14. May/ June.

[37] PMI (Project Management Institute). A guide to project management body of knowledge: PMBOK (Project Management Book of Knowledge) Guide. 2nd ed. Upper Darby, PA, USA; 2000.

[38] Baghdadi, A, Kishk, M., (2015). "Saudi Arabian aviation construction projects: Identification of risks and their consequences". Procedia Engineering 123 (2015) 32-40.

[39] Khodeir, L., Mohamed, A., (2014). "Identifying the latest risk probabilities affecting construction projects in Egypt according to political and economic variables". Housing and Building National Research Center, HBRC Journal (2015) 11, 129-135.

[40] Rafindadi, A., Miki, M., Kovai, I. and Ceki, Z., (2014). "Global Perception of Sustainable Construction Project Risks", 27 th IPMA World Congress, Procedia- Social and Behavioral Sciences 119 (2014) 456-465.

[41] Tanaka, H., (2014). "Toward project and program management paradigm in the space of complexity: a case study of mega and complex oil and gas development and infrastructure projects". 27 th IPMA World Congress, Procedia- Social and Behavioral Sciences 119 (2014) 65-74.

[42] Toh, T., Ting, C., Ali, A., Aliagha, G. and Munir, O., (2012). "Critical cost factors of building construction projects in Malaysia". International Conference on Asia Pacific Business Innovation and Technology Management, Procedia - Social and Behavioral Sciences 57 (2012) 360-367. 